
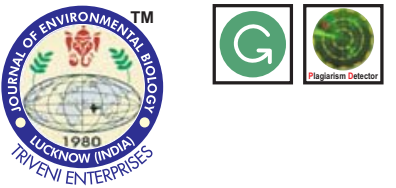

DOI : http://doi.org/10.22438/jeb/38/6(SI)/01

ISSN: 0254-8704 (Print)

ISSN: 2394-0379 (Online)

CODEN: JEBIDP

\title{
Ciliates and trophic state: A study in five adjacent urban ponds in Mexico City
}

Authors Info

A. Lugo-Vázquez *

M.R. Sánchez-Rodríguez, J. Morlán-Mejía', L. Peralta-Soriano',

E. A. Arellanes-Jiménez², M. A. Escobar-Oliva ${ }^{2}$, and M.G. Oliva-Martínez ${ }^{2}$

${ }^{1}$ Proyecto de Investigación en Limnología Tropical, FES Iztacala, Universidad Nacional Autónoma de México (UNAM). Av. de los Barrios No. 1, Los Reyes Iztacala, Tlalnepantla, C.P. 54090, Estado de México, México

${ }^{2}$ Carrera de Biología, FES Iztacala, UNAM, Av. de los Barrios, No. 1 Los Reyes Iztacala, Tlalnepantla, C.P. 54090 , Estado de México, México

*Corresponding Author Email : lugov@unam.mx

\section{Key words}

Ciliate biomass

Eutrophic conditions

Plankton

Protozooplankton

Shallow lakes

Publication Info

Paper received: 16.07 .2016

Revised received : 08.05.2017

Re-revised received: 07.06.2017

Accepted:03.07.2017

\section{Abstract}

Aim: The ciliated protozoa are components of the microbial food web. A relationship between species richness, number, and size of ciliates, and the trophic state has been recognized in some works. The aim of this study was to determine how the trophic differences affect the protozooplankton composition, abundance, and biomass considering the similarity in location and climatic conditions in five adjacent shallow urban water bodies in Mexico City with differences in trophic state.

Methodology: Monthly protozooplankton samplings were conducted from January to December 2015 and measured water temperature, dissolved oxygen, specific conductance, pH and Secchi disk, RDP, TP, and chlorophyll a. Integrated column samples for ciliates were obtained and taxonomic richness, species density, and biomass by size class calculated using in vivo, stained and Lugol fixed samples. ANOVA was applied for environmental data comparison, and cluster analyses were carried out using environmental and biological data. A redundancy analysis was used to explain the variation of the ciliates biomass related to physicochemical conditions.

Results: Ciliate densities and biomass varied accordingly with the trophic state and showed higher values in the more productive ponds, and lower values in the other ponds. Oligotrichia and Prostomatea were the dominant taxonomic groups. Eastern Quarry ponds trophic state varied from oligotrophic to near hypertrophic and abundance and biomass variation of planktonic ciliates followed a trophic gradient, showing higher values in more eutrophic systems. Ciliates in the range body size of 30-50 $\mu \mathrm{m}$ dominated the biomass in the ponds. An unexpected result was the low species number and densities of the small size ciliates (mainly Scuticociliatida) that often are important in eutrophic conditions.

Interpretation: The relationship between the trophic state and the abundance and biomass of plankton ciliates was confirmed. The size fraction $<20 \mu \mathrm{m}$ was not important, and the 30-50 $\mu \mathrm{m}$ body size ciliates were dominant even in the most productive ponds.

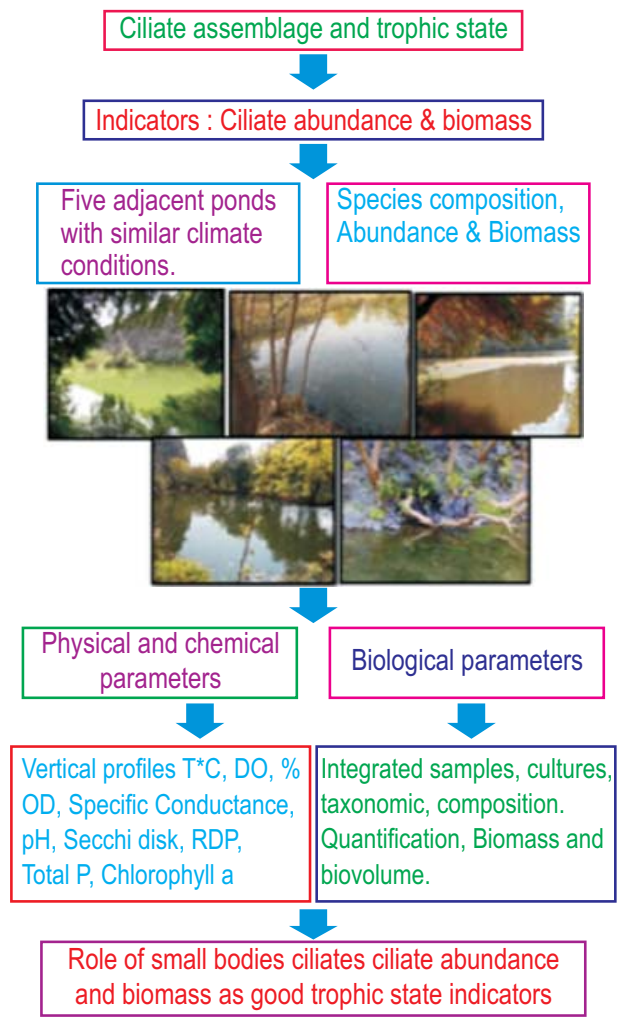




\section{Introduction}

Urban lakes are ecosystems that suffered from pollution and eutrophication (Schueler y Simpson 2003, Nasseli-Flores 2008). Eutrophication causes significant changes in the system components, especially in plankton communities favoring the increase of primary production and the emergence and dominance of potentially toxic organisms such as cyanobacteria (Sommaruga, 1995).

The ciliated protozoa are components of the microbial food web and they have some ecological functions: they are important consumers of bacteria (Chróst et al., 2009) and phytoplankton grazers (Lischke et al., 2016). They feed on autotrophic picoplankton (Buholce et al., 2015), and transfer energy to higher trophic levels, for example to the rotifers, cladocerans, and copepods (Adrian and Schneider-Olt, 1999). It has been suggested that ciliates may enhance nutrient availability for phytoplankton (Xu and Cronberg, 2010). Recent studies show that ciliates are a significant part of the diet of the larvae of different fish species (Zingel et al., 2012).

Relationship between species richness, number and size of ciliates, and trophic state was long known (Beaver and Crisman 1982; Beaver and Crisman 1989). This relationship has been found in other studies, though not always in the same way. While some authors believe that the importance of microbial webs is higher in oligotrophic environments (Weisse, 1991, Macek et al., 2006) others argue that in highly productive environments where large filter feeders like Daphnia are absent, small size grazers, including ciliates, can become important (Sommaruga, 1995). When fish predation pressure on zooplankton is very high, small size filter feeders may be the main phytoplankton grazers in the systems (Lischke et al., 2016).

In this paper, composition and abundance of protozooplankton were compared in five shallow lakes (ponds) located in an urban ecological reserve (Reserva Ecologica del Pedregal de San Angel, REPSA). The water bodies are found in the grounds of an old mine of asphalt called the Eastern Quarry (Cantera Oriente, in Spanish). These ponds are fed by several springs and are found adjacent. Despite their closeness and sharing the same source of water, the waterbodies have differences in their trophic status that are observable to the naked eye.

The aim of this study was to determine how the trophic differences affect protozooplankton composition, abundance, and biomass considering the similarity in location and weather conditions.

\section{Materials and Methods}

Study area : The Eastern Quarry is a part of the REPSA (Ecological Reserve of Pedregal of San Angel) and is located on the campus of the National Autonomous University of Mexico

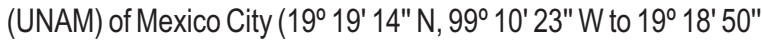
$\left.\mathrm{N}, 99^{\circ} 10^{\prime} 16^{\prime \prime} \mathrm{W}\right)$. REPSA vegetation dominance corresponds to high elevation desert scrub, and the main species is Pittocaulon praecox (Palo loco). The substrate is mostly volcanic rock (Peralta-Higuera and Prado-Molina 2009).

The Eastern Quarry is an area of approximately 206,000 $\mathrm{m}^{2}$. In 1970 the extraction of rock began on this site, but at some time the drilling reached the level of groundwater and the water began to sprout, forming small ponds. Rock extraction no longer continued and in 1996 the UNAM joined this area to the REPSA (Lot, 2007). Thereafter, a restoration process began and exotic plants were introduced. Currently, in Eastern Quarry there are four shallow lakes $(Z<1.5 \mathrm{~m})$ comprising an area of $11,906.45 \mathrm{~m}^{2}$ ( $14.36 \%$ of the total area of the reserve zone) (Ortiz-Perez et al., 2007) (Fig. 1). These water bodies are supplied by several springs that flow from the rock walls surrounding the area (Hernandez-Martinez, 2007).

Monthly samplings were conducted from January to December 2015. Sampling sites were the central point of four ponds: North, Center, South and Regulation and the puddle formed by one of the springs that fill them. At each site vertical profiles (every $0.2 \mathrm{~m}$ ) were measured in the water column of the

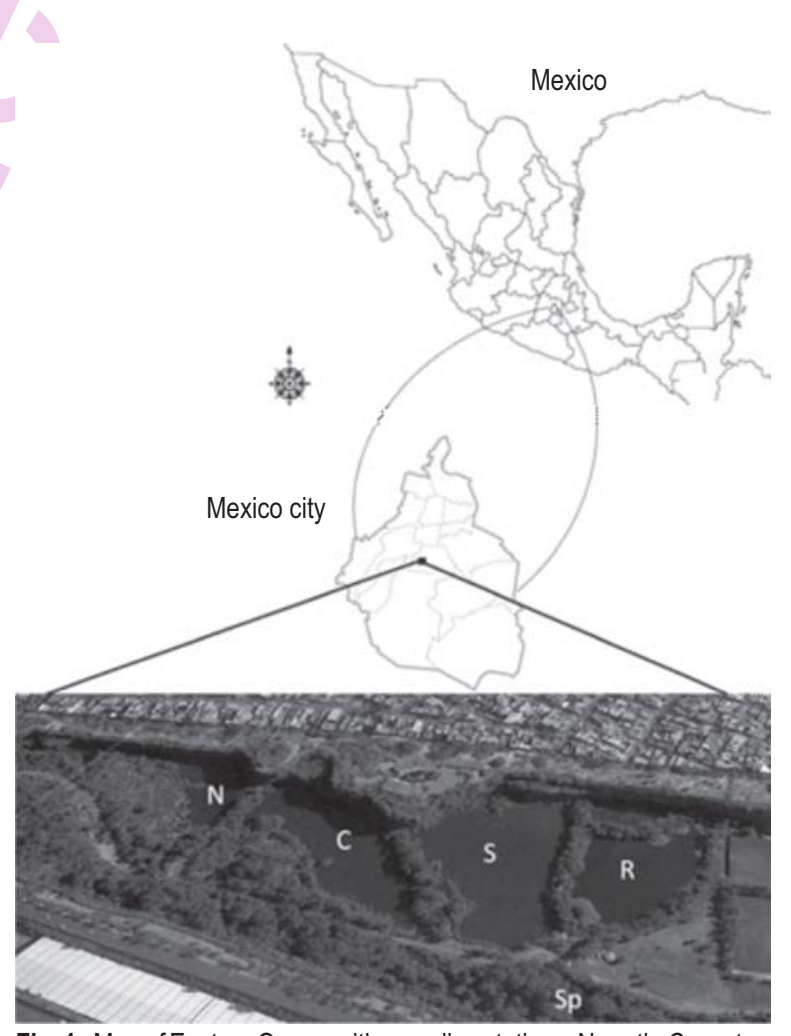

Fig. 1 : Map of Eastern Quarry with sampling stations. N:north; C: center; S: south; R: regulation; Sp: spring. Photo from Google Earth 
following variables: water temperature, dissolved oxygen concentration, D.O. saturation percentage and specific conductance at $25^{\circ} \mathrm{C}$ using a Multi-probe YSI (Cincinnati, USA) model 85. The $\mathrm{pH}$ was measured with a Conductronic (Puebla, Mexico) model $\mathrm{pH} 10$ potentiometer. Secchi disk visibility was measured using a $0.20 \mathrm{~m}$ diameter black and white disk.

Integrated samples of the water column in each pond were taken using an acrylic tube sampler ( $26 \mathrm{~mm}$ diameter). Duplicate $50 \mathrm{ml}$ samples were obtained for ciliates. One sample was maintained in dark and temperate conditions for in vivo observation of organisms. The other samples were fixed with $1 \%$ acid Lugol (Finlay and Guhl 1992). Fresh plastic containers (500 $\mathrm{ml}$ ) were used for Reactive Dissolved Phosphorous (RDP) samples. These samples were transported to the laboratory at $4^{\circ} \mathrm{C}$. For chlorophyll a determination, fresh samples of $50 \mathrm{ml}$ were collected in polypropylene tubes and a variable volume ( 5 to $30 \mathrm{ml}$ ) filtered in situ using Whatman $\circledR_{\text {GF }}$ / F glass fiber filters with the help of a manual vacuum pump.

RDP was measured by the ascorbic acid spectrophotometric method (APHA 2012). Total phosphorus was measured by the alkaline digestion method (Valderrama,1981), and organic phosphorus was calculated form the difference between total and reactive $P$ Chlorophyll a concentration was obtained using a Turner Designs $₫$ Model 10-AU fluorometer and the cold extraction method $\left(4^{\circ} \mathrm{C}\right)$ with $90 \%$ acetone following Arar and Collins (1997). The ciliates samples were observed in vivo and using vital staining dyes (Lee et al. 2000). Some ciliate species were cultured using filtered lake water and Chalkley medium with wheat grains. Silver staining techniques were applied for selected species (Lynn, 1992).

Lugol fixed samples were counted in a Sedgwick-Rafter chamber (1.0 ml) (Finlay and Guhl 1992). A minimum of 100 organisms of the most abundant species (Wetzel and Likens 2001) were counted with a Zeiss microscope model K7 (160X).

The taxonomic keys used for ciliate identification were Foissner and Berger (1996); Foissner et al. (1991, 1992, 1994, 1995, and 1999), and Lynn and Small (2000).

At least 20 individuals of each species were measured in vivo for biomass calculation, using a calibrated micrometer. The shape of each species was approximated to the nearest geometric form according to Sun and Liu (2003). Biovolume was transformed into biomass assuming a specific density of 1.0.

For comparison of the environmental variables between the lakes, ANOVA analyses were performed. A hierarchical cluster analysis was applied using environmental data from the ponds. Pearson $r$ was used as similarity index and the intragroups cluster method (IBM SPSS ver. 19, 2010). Log ( $n+1)$ transformed total abundances were also compared using
ANOVA. Ciliate community composition in the ponds was compared using the similarity Bray-Curtis Index and grouped by the simple linkage hierarchical method with the PAST statistical package (ver. 3.62015).

Redundancy analysis was applied to explain the variation of the ciliates biomass in relation to physicochemical conditions (CANOCO Program ver. 4.5.1)

\section{Results and Discussion}

Environmental conditions : Water temperature, conductivity, and $\mathrm{pH}$ did not show significant differences $(\mathrm{P}>0.05)$ among the ponds of the Eastern Quarry (table 1). Water temperature fluctuated between 13.3 and $21^{\circ} \mathrm{C}$, conductivity from 377 to 491 $\mu \mathrm{S} \mathrm{cm}^{-1}$ and the $\mathrm{pH}$ conditions were from neutral (6.8) to alkaline (9.7).

Oxygen saturation showed significant differences $(\mathrm{P}<$ $0.05)$ between ponds. South and Center ponds with averages of 195 and $216 \%$ were different from the North (142\%) and Regulation (158\%) ponds and from the Spring (89\%).

Secchi disk transparency ranged from $0.15 \mathrm{~m}$ in the South pond to $1.3 \mathrm{~m}$ for Regulation pond and showed an inverse relationship with chlorophyll a values. Regulation Pond and Spring, with the higher average transparency values (1.15 and $0.65 \mathrm{~m}$ ) had the lowest chlorophyll a mean concentration (14 and 7 $\left.\mu \mathrm{gl}^{-1}\right)$. The South pond showed the minimum average value of transparency $(0.35 \mathrm{~m})$ but the maximum mean value of chlorophyll a $\left(188 \mu \mathrm{g} \mathrm{l}{ }^{-1}\right)$, followed by the Center $\left(0.45 \mathrm{~m}\right.$ and $\left.164 \mu \mathrm{g} \mathrm{l} \mathrm{I}^{-1}\right)$. The North pond had intermediate values of transparency $(0.82 \mathrm{~m})$ and also a moderate value of chlorophylla (56 $\mathrm{ggl}^{-1}$ ) (Table 1).

The RDP behavior also had an inverse relationship with chlorophyll a. The most productive water bodies (South and Center) presented the lower mean concentrations of $\operatorname{RDP}(0.03$ and $\left.0.05 \mathrm{mg} \mathrm{l}^{-1}\right)$. RDP concentration in the Spring was the higher $\left(0.12 \mathrm{mg} \mathrm{l}^{-1}\right)$ and the Regulation pond also had a high average (0.1 $\left.\mathrm{mgl}^{-1}\right)$. The North pond was in the middle with a mean of $0.08 \mathrm{mg} \mathrm{l}^{-}$ 1. When ANOVA was applied to RDP data the Center and South ponds were different $(P<0.05)$ from the other three ponds. RDP consume by phytoplankton may explain the inverse relationship of this nutrient with chlorophyll a concentrations. Our data also show that Spring water source to the ponds provides significant RDP concentrations and may a factor that causes the observed eutrophic conditions.

A hierarchical cluster analysis (Fig. 2) was carried out using the environmental variables data of the five water bodies. Two clearly separated groups were formed. The first includes the Center, South and North ponds, which shared high levels of chlorophyll a and dissolved oxygen saturation, low transparency, and low RDP concentrations; this group corresponds to eutrophic ponds. In the second group the Regulation pond and Spring were 
Table 1: Variation range and mean values of physical and chemical variables in the five ponds of Eastern Quarry

\begin{tabular}{llllll}
\hline & North & Center & South & Regulation & Spring \\
\hline Temperature $\left({ }^{\circ} \mathrm{C}\right)$ & $13.3-18.5(16.4)$ & $14.7-19.8(17.5)$ & $16.4-21(18.72)$ & $16.3-19.5(17.7)$ & $16.1-17.8(17)$ \\
& $6.8-8.25$ & $8.7-9.7$ & $8.1-9.6$ & $6.9-8.3$ & $6.9-8.1$ \\
pH & $(7.7)$ & $(8.9)$ & $(9.2)$ & $(7.8)$ & $(7.3)$ \\
Conductivity $\left(\mu \mathrm{S} \mathrm{cm}^{-1}\right)$ & $377-480(436)$ & $381-472(426)$ & $382-422(406)$ & $390-452(418)$ & $396-491(445)$ \\
$\%$ Oxygen Sat. & $75-223(142)$ & $103-267(195)$ & $130-260(216)$ & $96-237(158)$ & $66-128(89)$ \\
Secchi disk $(\mathrm{m})$ & $0.45-1.10(0.82)$ & $0.35-0.60(0.45)$ & $0.15-0.55(0.35)$ & $1.00-1.30(1.15)$ & $0.50-1.00(0.65)$ \\
Chlorophyll $a\left(\mu \mathrm{gl}^{-1}\right)$ & $13-114(56)$ & $74-274(164)$ & $58-468(188)$ & $6-24(14)$ & $2-36(7)$ \\
P-dissolved $\left(\mathrm{mgl}^{-1}\right)$ & $0.06-0.1(0.08)$ & $0.01-0.09(0.05)$ & $0.01-0.07(0.03)$ & $0.09-0.15(0.1)$ & $0.1-0.15(0.12)$ \\
P-total $\left(\mathrm{mg}^{-1}\right)$ & $0.08-0.29(0.17)$ & $0.19-0.72(0.42)$ & $0.19-1.27(0.53)$ & $0.10-0.17(0.14)$ & $0.12-0.16(0.14)$ \\
P-organic $\left(\mathrm{mgl}^{-1}\right)$ & $0.02-0.22(0.08)$ & $0.03-0.33(0.13)$ & $0.10-0.97(0.17)$ & $0.00-0.06(0.03)$ & $0.00-0.03(0.02)$ \\
\hline
\end{tabular}

Table 2 : List of ciliate species recorded in the lakes of the Eastern Quarry. ++ indicates new records to the area

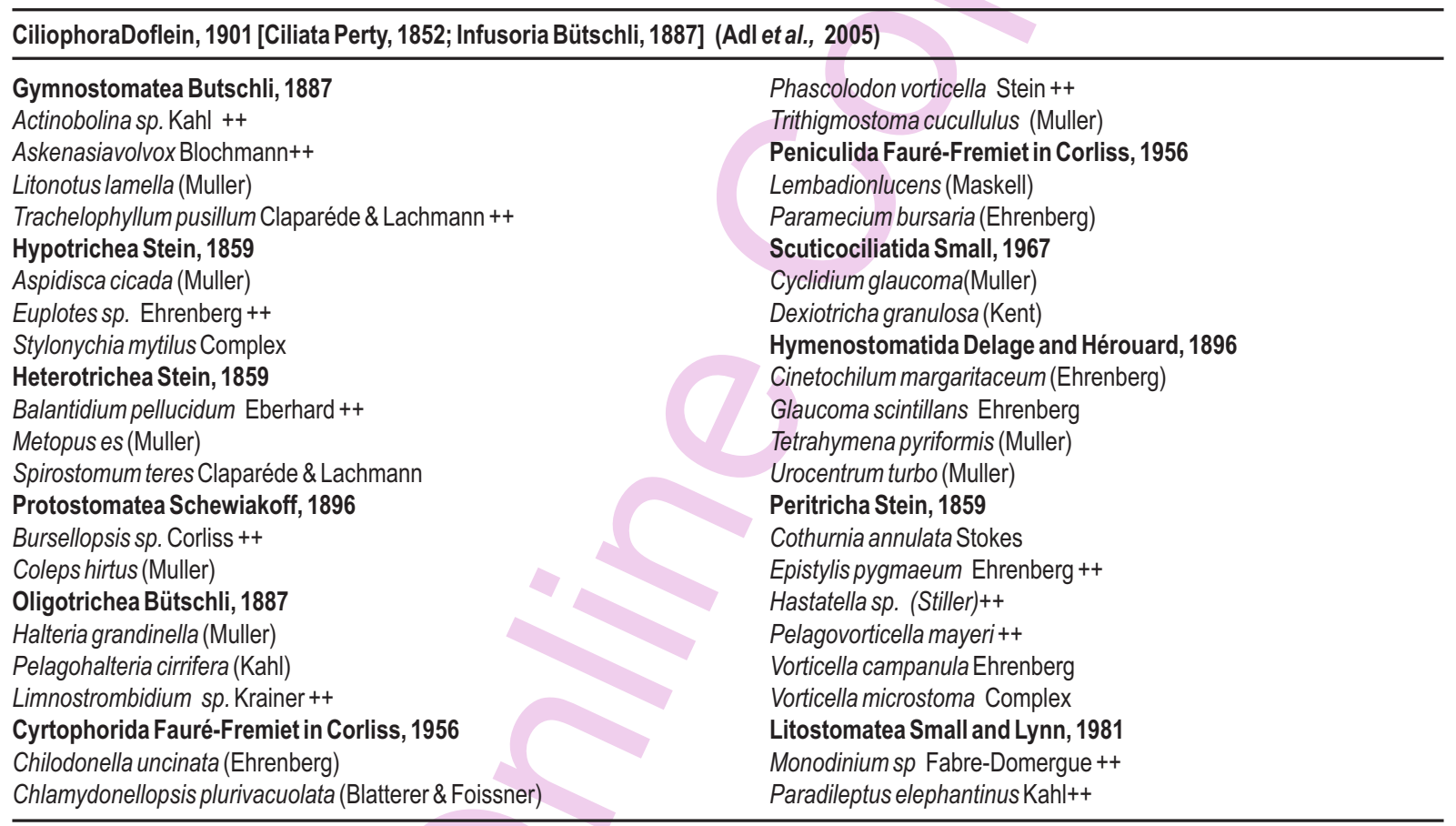

joined because they share low values of chlorophyll a, moderately oxygen saturation, lower $\mathrm{pH}$ values, but higher concentrations of $\mathrm{RDP}$; this means a lower trophic state.

Taxonomic composition of planktonic ciliates : Thirty-five ciliate morphospecies were observed in the plankton samples from Eastern Quarry ponds (Table 2). Species richness was as follows: North Lake 23 species, Center Lake 26, South pond 25, 13 species in the Regulation pond and just seven in the Spring. Bagatini et al. (2013) in a study conducted in 13 water bodies in urban and rural areas of San Paulo, Brazil, found 20.6 as the average number of species of ciliates in every lake and a range between 3 and 66 . The average value of lakes in Brazil is similar to the most productive lakes in the Eastern Quarry.
Machado-Velho et al. (2013) identified 35 species of ciliates in two climatic periods in a eutrophic urban lake located in the city of Maringa, State of Parana, Brazil. In contrast, Buholce et al. (2015) found only 13 taxa in a study conducted in two ponds and two urban reservoirs in the city of Riga, Latvia, corresponding to the temperate zone of the world. Esquivel et al. (2016) in a tropical, deep and large lake (Catemaco, Mexico) identified 28 species of planktonic ciliates. The species richness in water bodies of Eastern Quarry is in the middle of the observed range found in other urban and natural bodies of water in different climatic regions.

Aladro-Lubel et al. (2007) found 75 species of ciliates in the same study site. However, in their research samples were 


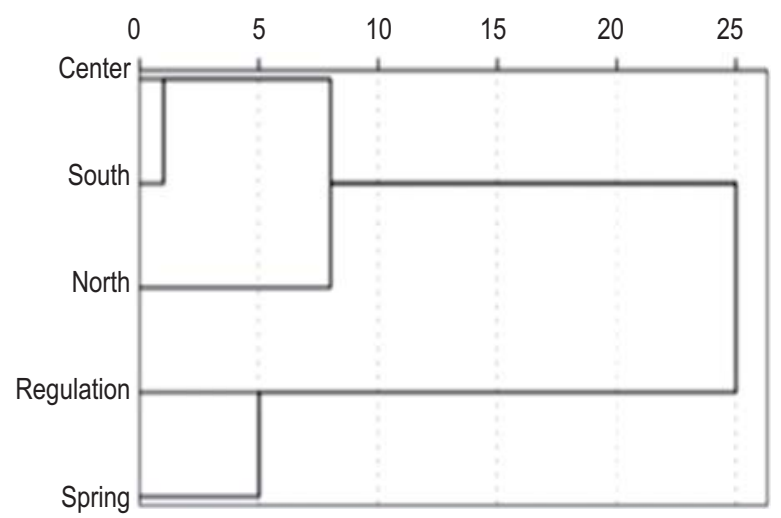

Fig. 2 : Hierarchical clustering of the aquatic bodies in the Eastern Quarry based on the log transformed data of the environmental variables. Similarity: 1-r Pearson

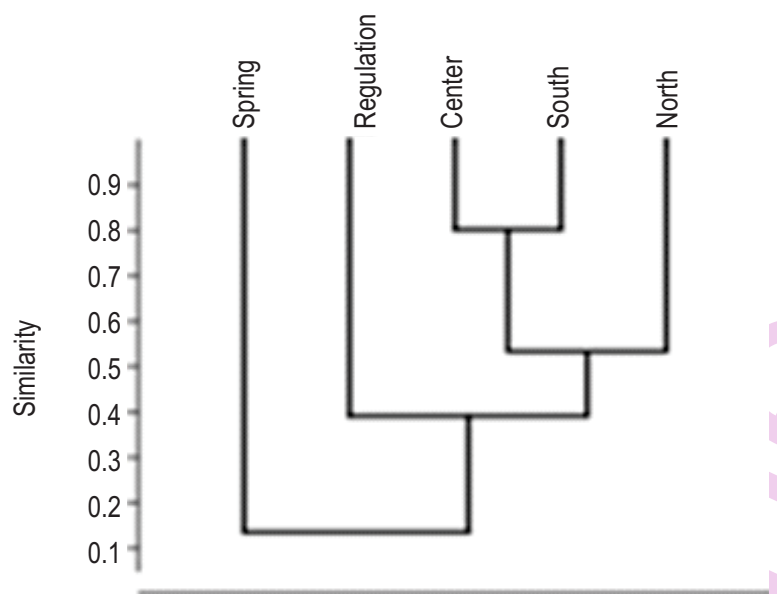

Fig. 4 : Cluster analysis (Bray-Curtis Similarity Index, Hierarchical cluster) of Eastern Quarry ponds using ciliate species abundances

taken from the littoral area of the ponds and channels, and from aquatic plants and sediment. The higher diversity of studied habitat may explain the greater species richness obtained by them. However, in our study 13 species not found previously were observed. Most of these species are true planktonic, as Limnostrombidium sp., A. volvox, Bursellopsis sp., P. vorticella, Monodinium sp., P. mayeri, and Hastatella sp., but other were associated with the littoral area. E. pygmaeum was observed as epibiont on rotifers and cladocerans, as described by Gilbert and Schröder (2003)

Species abundances : The species present in the four ponds and Spring were Halteria grandinella, Coleps hirtus, Limnostrombidium sp. and Pelagohalteria cirrifera. Overall, Limnostrombidum sp. showed the highest average abundances (North 16 ind $\mathrm{ml}^{-1}$, Center 23 ind $\mathrm{ml}^{-1}$, South 28 ind $\mathrm{ml}^{-1}$ ). It was the dominant species in the Regulation pond $\left(15\right.$ ind $\left.\mathrm{m} \mathrm{l}^{-1}\right)$ and the Spring $\left(3\right.$ ind $\left.\mathrm{m} \mathrm{l}^{-1}\right)$. C. hirtus dominated the abundance in the

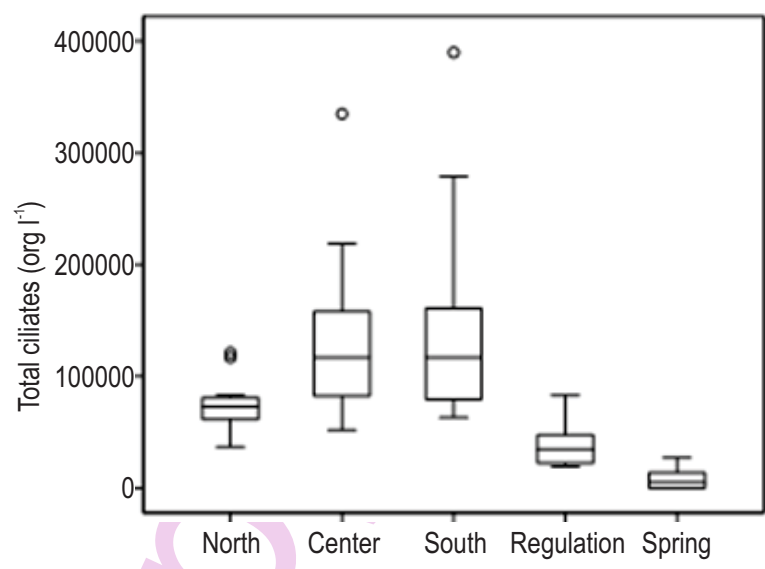

Fig. 3 : Box and whisker plot of the ciliate total abundance in the Eastern Quarry ponds

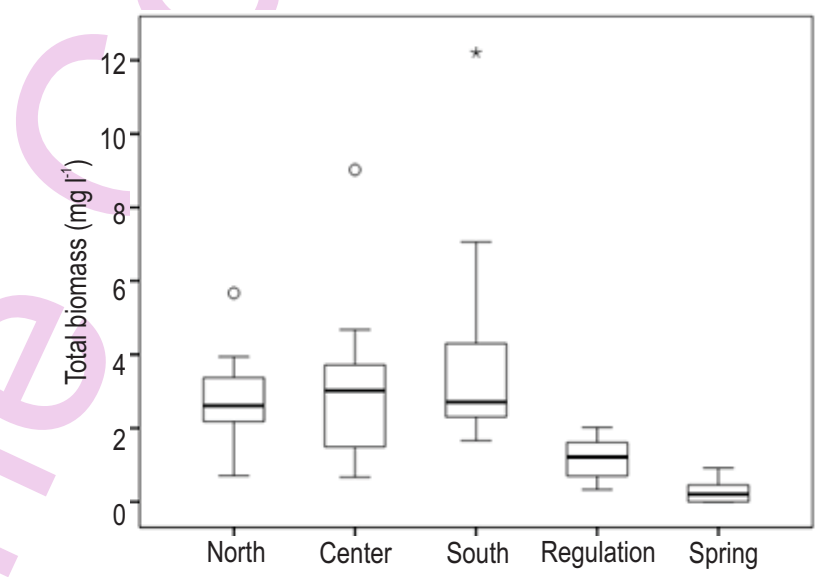

Fig. 5 : Box and whisker plot of ciliate total biomass ( $\mathrm{mg} \mathrm{l}^{-1}$ wet weight) in the five water bodies of the Eastern Quarry

Center $\left(30\right.$ ind $\left.\mathrm{m} \mathrm{l}^{-1}\right)$ and South $\left(40\right.$ ind $\left.\mathrm{m} \mathrm{l}^{-1}\right)$ ponds, whereas $H$. grandinella was the most abundant species in North (average 21 ind $\mathrm{ml}^{-1}$ ).

These species are the most common in the plankton of water bodies in different parts of the world. For example, $\mathrm{H}$. grandinella has a wide distribution in water bodies of Brazil (Bagatini et al., 2013). Also in many lakes of the temperate region, the genus Halteria is usually present with significant abundances (Buholce et al., 2015). Pelagohalteria cirrifera (formerly Halteria cirrifera) is equally dominant and widely distributed in lakes of different latitudes. Limnostrombidum (formerly Strombidium), another Oligotrichea genus, has been also found in many sites (Beaver and Crisman 1982; Machado-Velho et al. 2013).

These three species belong to the Oligotrichea group (Foissner et al., 1999) that is usually the most abundant in plankton biomass in the lakes (Beaver and Crisman 1989, 
Buholce et al. 2015). Prostomatea (which includes C. hirtus) is also of high importance in the protozooplankton abundance in many water bodies (Machado-Velho et al., 2013).

In the ponds of Eastern Quarry, the Oligotrichea represented the largest percentage of the total number of ciliates found in the 5 sampling sites, providing from $65 \%$ in the North to about $40 \%$ in the Center and South ponds. The Protostomatea (represented only by C. hirtus) contributed between 25 and $30 \%$ of total abundance in Center and South ponds. The other 10 taxonomic groups contributed globally with about $30 \%$ of the total abundance, with the exception of the Regulation pond where their contribution was slightly higher (35\%).

Peritricha were the group with the largest number of species (6). However, their abundances were not very high in any case. Vorticella campanula, V. microstoma and Pelagovorticella mayeri were the main representatives of this group. Epystilis pygmaeum was observed as epibiont on Moina micrura, a cladoceran species found in North and Center ponds.

Total abundances of ciliates : The variation of the total abundance of ciliates between ponds was remarkable (Fig. 2). The most productive ponds (South and Center) had the highest range: $68000-390000$ org l$^{-1}$ in the South and $52000-335000$ org l $^{-}$ ${ }^{1}$ in the Center. North pond had intermediate range (37000121000 org I $^{-1}$ ) and Regulation 19000-83000 org $\mathrm{I}^{-1}$; the lowest range was found in Spring $\left(0-27000 \mathrm{org} \mathrm{l}^{-1}\right)$.

Beaver and Crisman (1982) found the following values of total abundance of ciliates in subtropical Florida lakes in agreement with their trophic status in org $\mathrm{ml}^{-1}$ (mean $\pm \mathrm{SD}$ ): oligotrophic $10.4 \pm 5.4$; mesotrophic $27.5 \pm 7.7$; eutrophic $55 \pm$ 7.6 and $66 \pm 199$ hypertrophic. Values found in the Eastern Quarry ponds were: $148 \pm 96$ org m l$^{-1}$ (mean \pm SD) in the South, and $137 \pm 78 \mathrm{org} \mathrm{m} \mathrm{l}^{-1}$ in the Center. North pond had intermediate values $\left(74 \pm 21\right.$ org m l$\left.~^{-1}\right)$ and Regulation $38 \pm 19 \mathrm{org} \mathrm{ml}^{-1}$; lowest numbers was counted in Spring $\left(8 \pm 10\right.$ org $\left.\mathrm{ml}^{-1}\right)$. Taking into consideration the above, the trophic state of Eastern Quarry ponds based on ciliate numbers would be as follows: Spring is oligotrophic, Regulation pond mesotrophic, North, Center and South ponds, eutrophic, but the last two with values very close to those of the hypertrophic conditions. Chlorophyll a mean concentration and Secchi disk measures also support this point of view. The result of the cluster analysis of the ponds using the data of environmental variables indicated the same differences.

The ANOVA applied to compare the total ciliate abundances between lakes showed that North, Center and South ponds mean values were higher and different $(P<0.05)$ than those from the Regulation pond and Spring as can be appreciated in Fig. 3. Likewise, a hierarchical cluster of the lakes using ciliates abundance, and the Bray-Curtis similarity index (Fig. 4), grouped the three most eutrophic lakes (South, Center and North) and in a

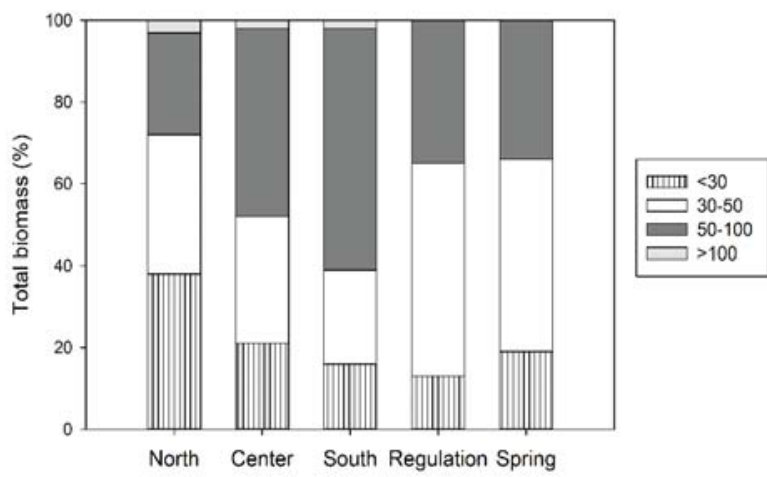

Fig. 6 : Percentage contribution of ciliate size intervals to the total biomass in each water body

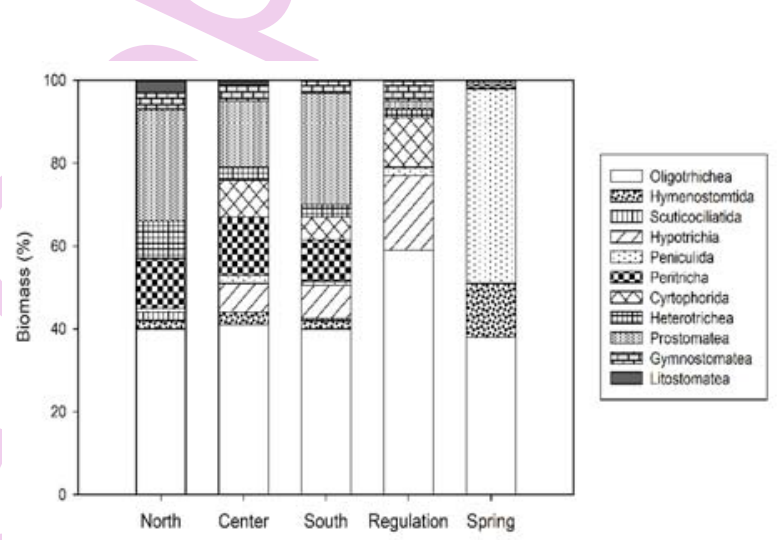

Fig. 7 : Biomass percentage contribution by taxonomic group in each pond

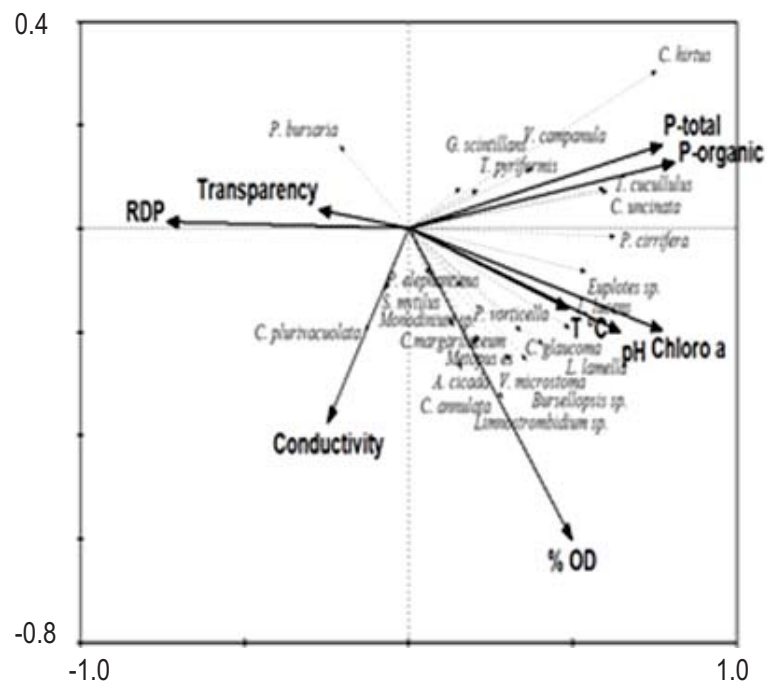

Fig. 8 : Redundancy analysis of planktonic ciliates species biomass and physico-chemical variables 
different group the other two water bodies, with the lower trophic state. A cluster analysis of lakes using environmental data (Table 1) was coincident and confirm the similarity of eutrophic conditions in the Center and South ponds, as well, in the North. Regulation pond and Spring had a variable but a lower trophic state.

Size variation : Size variation of species had a particular behavior. Only three species (H. grandinella, Cyclidum glaucoma and Cinetochilum margaritaceum) had a size $\leq 30 \mu \mathrm{m}$. The size of 15 species was between 30 and $50 \mu \mathrm{m}$, and also 15 species were found between 50 and $100 \mu \mathrm{m}$. Finally, only two species were larger than $100 \mu \mathrm{m}$ (Spirostomum teres and Lembadion sp.)

Beaver and Crisman (1989b) observed a replacement of large body ciliate species (mainly from the group of Oligotrichea) by small-body size species (mainly Scuticociliatida) as trophic state increases. The results of this study do not agree with this, as the number of species of the small size found in all ponds was very low (3). As occurred in Latvian urban and rural lakes (Buholce et al. 2015) species in the range size of 30-50 $\mu \mathrm{m}$ dominate in the North (11 sp.), South (11) and Regulation (6) ponds and in the Spring (4) whereas the range of 50-100 $\mu \mathrm{m}$ predominated in Center pond (12 sp.) and occupied the second place in importance in North (8), South (11), Regulation (6) and in the Spring (2).

Biomass : Ciliate biomass in the ponds varied according to the trophic state (Fig. 5). The South and Center ponds, the more eutrophic water bodies, had the highest median biomass (wet weight) values (3.0 mg l-1 in North and $2.8 \mathrm{mg} \mathrm{l}^{-1}$ in South pond) followed by the North pond $\left(2.6 \mathrm{mg} \mathrm{I}^{-1}\right)$. In contrast, median biomass values in the Regulation pond $\left(1.6 \mathrm{mg} \mathrm{I}^{-1}\right)$ and Spring $(0.7$ $\left.\mathrm{mgl}^{-1}\right)$ were much lower. Biomass fluctuation in Center and South ponds was highly variable reaching maximum values of $9.6 \mathrm{mgl}^{-1}$ in North and $12.2 \mathrm{mg} \mathrm{l}^{-1}$ in South.

Biomass behavior in the ponds agrees with the statement that ciliate biomass increases with the trophic state (Beaver and Crisman 1982; Zou et al., 2013). Some authors proposed that the increase in nutrient availability favors higher abundance of bacteria and phytoplankton, both important food resources for planktonic ciliates (Machado-Velho et al., 2005; Buholce et al., 2015).

Percentage of biomass per ciliate size intervals : The contribution to the biomass of each size intervals of ciliates is shown in Fig 5. The 30-50 $\mu \mathrm{m}$ size class contribution to biomass was the higher in North (56\%) Center (55\%) and Regulation (55 $\%$ ) ponds and in the Spring (68\%). In the South pond, the range size of $50-100 \mu \mathrm{m}$ formed the main portion of the biomass (48.5 $\%$ ), barely surpassing the $30-50 \mu \mathrm{m}$ range (47.5\%). The next size range was $50-100 \mu \mathrm{m}$ that varied from $48.5 \%$ in the South to $24 \%$ in the Spring. The range below $30 \mu \mathrm{m}$ represented $11 \%$ in the North and only $3.8 \%$ in the Spring. Ciliates $>100 \mu \mathrm{m}$ contributed less than $5 \%$ in all ponds except in the North where they contributed $7.5 \%$ of the biomass. The relation of biomass to body size of the ciliate species did not agree with the results of Beaver and Crisman (1989b) because in Eastern Quarry the small size class was not important for biomass in any water body.

Percentages of biomass by taxonomic groups : Oligotrichea provides the main portion of ciliate biomass in the four ponds. The contribution was around $40 \%$ in North, Center and South ponds and up to $60 \%$ in the Regulation pond. In the Spring, with the lowest trophic status, Peniculid (Paramecium bursaria) constitute the largest percentage of the biomass, followed by Oligotrichea ( $H$. grandinella and Limnostrombidium sp.). Prostomatea (C. hirtus) was the second contributor to biomass in North and South (about 30\%) ponds but lower in the Center pond (less than $20 \%$ ). This group was not important in Regulation pond and it was absent in Spring (Fig.6)

Peritricha contribution was about $10 \%$ in the North, Center and South ponds, but negligible in the Regulation and Spring. Cyrtophorida contributed slightly less than $10 \%$ of the biomass in the South, Center and Regulation, while Heterotrichea accounted for $7 \%$ in the North and $<5 \%$ in the South and Regulation ponds.

Hypotrichea contribution was higher in the Regulation pond (15\%) and lower in the Center (7\%) and South (6\%); Gymnostomatea only contributed between 3.75 (North, Center and South) and 5.75 in the Regulation pond. A remarkable fact is that Scuticociliatida had not a significant biomass in any of the most productive lakes (South and Center) and there was a visible contribution $(2 \%)$ only in the North pond. This differs from that found by Beaver and Crisman (1982) who found that small-body ciliates $(<30 \mu \mathrm{m})$, mainly belonging to Scuticociliatida, were prevalent at high trophic states.

Environment-species relationship: In the Redundancy analysis (RA) the first two axes explained the $79.7 \%$ of the ciliate biomass variation (Axis 1: $65.3 \%$, axis 2: 14.4\%). Most species were related with trophic state associated variables as chlorophyll a, \% O.D., pH and total an organic phosphorous, as well as temperature (Fig. 8). Many ciliate species related with these conditions but $P$. vorticella, Lembadion sp., Bursellopsis sp., and Limnostrombidium sp. are notorious because they are important phytoplankton and picoplankton grazers. Other species also related with eutrophic conditions were mainly bacterivorous as $V$. microstoma, C. glaucoma, A. cicada, C. annulata, and Euplotes sp. Other species, as $C$. hirtus, V. campanula, $T$. pyriformis, and $G$. scintillans were specially related with high values of both total and organic phosphorous and could be also considered as eutrophic conditions indicators. On the other hand, $C$. plurivacuolata, related with conductivity, and $P$. bursaria, present in transparent water (Spring), could be indicators of better trophic conditions. 
Ciliate species composition in the ponds of the Eastern Quarry showed significant similarities with other freshwater bodies in very different latitudes in the world. The dominant groups (Oligotrichea, Prostomatea) are also common in many other aquatic ecosystems. Eastern Quarry ponds trophic state varied from oligotrophic to near hypertrophic and abundance and biomass variation of planktonic ciliates was according with this gradient, showing higher values in more eutrophic water bodies. Medium size ciliates (30-50 $\mu \mathrm{m})$ provided most of the biomass, while very small $(\leq 30 \mu \mathrm{m})$ or very large $(>100 \mu \mathrm{m})$ species provided a low percentage. A major difference in the Eastern Quarry ponds was the low participation of the group of Scuticociliatida, both in abundance and biomass of all ponds. This group has been observed in high numbers in eutrophic conditions, but this did not happen in the eutrophic lakes studied.The abundance and biomass of planktonic ciliates in these water bodies were suitable signals of the trophic state differences.

\section{Acknowledgments}

This study was supported by PAPIIT project IN221115 (DGAPA, Universidad Nacional Autonoma de Mexico). We acknowledge the logistic support of Francisco Martínez Pérez and the REPSA authorities. Luis A. Nuñez Avila and Marlen Santiago Lima provided valuable support in field work.

\section{References}

Adrian, R. and B. Scheneider-Olt.: Top-down effects of crustacean zooplankton on pelagic microorganisms in a mesotrophic lake. J. Plankton Res., 21, 2175-2190 (1999).

Aladro-Lubel, M.A., M. Reyes-Santos, F. Olvera-Bautista and M.N. Robles-Briones: Ciliates and other protozoans. In: Illustrated Guide of the Eastern Quarry. Environmental characterization and biological inventory. (Coord. A. Lot). The National Autonomous University of Mexico. p. 97 (2007) (in Spanish).

APHA: Standard Methods for the examination of water and wastewater. $22^{\text {nd }}$ Edn., APHA, AWWA, WPCF, Washington DC, USA (2012).

Arar, E.J. and G.B. Collins: Method 445.0: In vitro determination of chlorophyll a and pheophytin a in marine and freshwater algae by fluorescence. Ohio: United States Environmental Protection Agency (EPA), Office of Research and Development, National Exposure Research Laboratory, USA(1997).

Bagatini, I.L., A.L.G. Spínola, B.M. Peres, A.S. Mansano, M.A.A. Rodrigues, M.A. Batalha, J.V. Lucca, M.J.L. Godinho, T.M. Tundisi, and M.H.R Seleghim: Protozooplankton and its relationship with environmental conditions in 13 water bodies of the Mogi-Guaçu basin - SP, Brazil. Biota Neotrop.,13, 152-163 (2013).

Beaver, J.R. and T.L. Crisman: The trophic response of ciliate protozoans in freshwater lakes. Limnol. Oceanogr., 27, 246-253 (1982)

Beaver, J.R. and T.L. Crisman: Analysis of the community structure of planktonic ciliate protozoa relative to trophic state in Florida lakes. Hydrobiologia, 174, 177-184 (1989a).

Beaver, J.R. and T.L. Crisman: The role of ciliated protozoa in pelagic freshwater ecosystems. Microbial Ecol., 17, 111-136 (1989b)

Beaver, J.R. and T.L. Crisman: Seasonality of planktonic protozoa in 20 subtropical Florida lakes of varying trophic state. Hydrobiologia, 190, 127-135(1990)

Buholce, L., V. Licite, E. Boikova and U. Botva: Structural composition of protozooplankton communities in relation to environmental factors in shallow lakes and reservoirs of Riga, Latvia. Proceedings of the Latvian Academy of Sciences (PLOSE) Sec. B., 69, 105-111 (2015).

Chróst, R.J., A. Tomasz, K. Kalinowska and Skowronska: Abundance and structure of microbial loop components (Bacteria and Protists) in lakes of different trophic status. J. Microbiol. Biotechnol., 19, 858-868 (2009).

Esquivel, A., A. Barani, M. Macek, R. Soto-Castor and C. Bulit.: The trophic role and impact of plankton ciliate in the microbial web structure of a tropical polymictic lake dominated by filamentous cyanobacteria. J. Limnol., 75, 93-106 (2016).

Finlay, B.J. and E.B. Guhl: Plankton sampling-freshwater. In: Protocols in protozoology (Eds.: J.J. Lee and A.T. Soldo). Society of protozoology. B1.1-B1.5. Kansas, USA(1992).

Foissner, W. and $H$. Berger: A user-friendly guide to the ciliates (Protozoa, Ciliophora) commonly used by hydrobiologists as bioindicators in rivers, lakes, and waste waters, with notes on their ecology., Freshwater Biol., 35, 375-482 (1996).

Foissner, W., H. Blatterer, H. Berger y F. Kohmann.: Taxonomische und ökologische Revision der Ciliaten des Saprobiensystems. Band I: Cyrtophorida, Oligotrichida, Hypotrichia, Colpodea. Informations berichte des Bayerischen Landesamtesfür Wasserwirtschaft. Deggendorf, Alemania (1991).

Foissner, W., H. Blatterer, H. Berger and F. Kohmann: Taxonomische und ökologische Revision der Ciliaten des Saprobiensystems. Band II: Peritrichia, Heterotrichida, Odontostomatida.Informationsberichte des Bayerischen Landesamtesfür Wasserwirtschaft. Deggendorf, Alemania (1992).

Foissner, W., H. Blatterer, H. Berger and F. Kohmann.: Taxonomische und ökologische Revision der Ciliaten des Saprobiensystems. Band III: Hymenostomata, Prostomatida, Nassulida. Informationsberichte des Bayerischen Landesamtesfür Wasserwirtschaft. Deggendorf, Alemania (1994).

Foissner, W., H. Blatterer, H. Berger and F. Kohmann.: Taxonomische und ökologische Revision der Ciliaten des Saprobiensystems. Band IV: Gymnostomatea, Loxodes, Suctoria. Informations berichte des Bayerischen Landesamtesfür Wasserwirtschaft. Deggendorf, Alemania (1995).

Foissner, W., H. Berger, J. Schaumburg: Identification and ecology of limnetic plankton ciliates. Informations berichte des Bayerischen Landesamtesfür Wasserwirtschaft. Deggendorf. Deggendorf, Alemania (1999).

Gilbert, J.J. and T. Schröder: The ciliate epibiont Epystilis pigmaeum: Selection for zooplankton hosts, reproduction and effect on two rotifers. FreshwaterBiol., 48, 873-893 (2003).

Hernández-Martínez, O., A. Quiróz-Flores, P. Ramírez-García and A. Lot:: Lacustrine landscape: ecology of aquatic vegetation. In: llustrated Guide of the Eastern Quarry. Environmental characterization and biological inventory. (Coord. A. Lot). National Autonomous University of Mexico. p. 45 (2007) (in Spanish).

Lee, J.J., O.F. Leedale and P. Bradbury: An illustrated guide to the protozoa. 2nd Edn. Society of Protozoologists, Laurence, Kansas, USA(2000).

Lischke, B.G., G. Weithoff, S.A. Wickham, K. Attermeyer, H.A. Grossart, K. Scharnweber, S. Hilt and U. Gaedke: Large biomass of small 
feeders: ciliates may dominate herbivory in eutrophic lakes. J. Plankton Res., 38, 2-15(2016).

Lot, A.: The Eastern Quarry: An introduction. In: illustrated Guide of the Eastern Quarry. Environmental characterization and biological inventory. (Coord. A. Lot). National Autonomous University of Mexico, p. 7 (2007) (in Spanish).

Lynn, D.H.: Protargol staining. In: Protocols in protozoology (Eds.: J.J. Lee and A.T. Soldo). Society of Protozoology. C4.1.-C4.10. Kansas, USA(1992).

Lynn, D.H. and E.B. Small.: Phylum Ciliophora, Doflein, 1901. In: An illustrated guide to the Protozoa (Eds.: J.J. Lee, G.F. Leedale and P. Bradbury). Society of Protozoologist. 2nd Edn., Lawrence, Kansas, pp. 371-656. (2000).

Macek, M., C. Callieri, K. Šimek and A. Lugo: Seasonal dynamics, composition and feeding patterns of ciliate assemblages in oligotrophic lakes covering a wide $\mathrm{pH}$ range. Arch. Hydrobiol., 166, 261-287 (2006).

Machado-Velho, L.F., F.M. Lansac-Toha, P.R. Bressan-Bousi, B. Ramos de Meira, A.F. Cabral and F.A. Lansac-Toha: Structure of planktonic ciliates community (Protist, Ciliophora) from an urban lake of southern Brazil. Acta Scientarum. Biological. Sci., 35, 531539 (2013).

Naselli-Flores, L.: Urban lakes: Ecosystems at risk, worthy of the best care. In: Proceedings of Taal 2007: The 12th World Lake Conference (Eds: M. Sengupta and R. Dalwani). IND, p. 1333. (2008).

Ortíz-Perez, M.A., J.M. Figueroa-Mah Eng, M.P. Salazar-Enciso, G. Parada-Colin and L. Castillo-Tellez.: Environmental units. In: Illustrated Guide of the Eastern Quarry. Environmental characterization and biological inventory. (Coord. A. Lot). The
National Autonomous University of Mexico. p. 15 (2007) (in Spanish).

Peralta-Higuera, A. and J. Prado-Molina: The limits and the cartography. In: Biodiversity in the Pedregal de San Angel ecosystem. (Eds.: A. Lot and Z. Cano-Santana). The National Autonomous University of Mexico. p. 27 (2009) (in Spanish).

Schueler, T. and J. Simpson: Why urban lakes are different? Watershed Prof. Tech., 3, 747-750 (2003).

Sommaruga, R.: Microbial and classical food webs: A visit to a hypertrophic lake. FEMS Microbial. Ecol., 17, 257-270 (1995).

Sun, J. and D. Liu.: Geometric models for calculating cell biovolume and surface area for phytoplankton. J. Plankton Res., 25, 1331-1346 (2003).

Valderrama, J.C.: The simultaneous analysis of total nitrogen and total phosphorous in natural waters. Mar. Chem., 10, 109-122 (1981).

Weisse, T.: The microbial food web and its sensitivity to eutrophication and contaminant enrichment: A cross-system overview. Int. Revue ges. Hydrobiol., 76, 327-337 (1991).

Wetzel, R.G. and G.E. Likens.: Limnological analyses. $2^{\text {nd }}$ Edn., W.B. Saunders Co. Philadelphia, USA(2001).

$\mathrm{Xu}, \mathrm{R}$. and G. Cronberg: Planktonic ciliates in Western Basin of Lake Rinsjön, Sweden, community structure, seasonal dynamics and long-term changes. Protistology, 6, 173-187. (2010).

Zingel, P., T. Paaver, K. Karus, H. Agasild and T. Nõges: Ciliates as the crucial food source of larval fish in a shallow eutrophic lake. Limnol. Oceanogr., 57, 1049-1056 (2012).

Zou, Q., Z. Lu, Ch. Li, Y. Li and P. Huang.: Seasonal pattern of planktonic ciliates in a subtropical shallow urban lake. Curr. Res. J. Biol. Sci., 5, 210-219 (2013). 